DOI: https://doi.org/10.32689/2523-4536/61-6

УДК 338.2

Кушлик О. Ю.

кандидат економічних наук, доцент,

Івано-Франківський національний технічний університет нафти і газу

Петрина М. Ю.

кандидат економічних наук, доцент,

Івано-Франківський національний технічний університет нафти і газу

Кочкодан В. Б.

кандидат економічних наук, доцент,

Івано-Франківський національний технічний університет нафти і газу

Kushlyk Oksana

$\mathrm{PhD}$ (Economics), Associate Professor, Ivano-Frankivsk National Technical University of Oil and Gas Petryna Mariya

$\mathrm{PhD}$ (Economics), Associate Professor, Ivano-Frankivsk National Technical University of Oil and Gas

Kochkodan Volodymyr

$\mathrm{PhD}$ (Economics), Associate Professor, Ivano-Frankivsk National Technical University of Oil and Gas

\title{
ЦІННІСТЬ БІЗНЕС-АНАЛІТИКИ ДЛЯ ПІДПРИСМСТВА В УМОВАХ ЦИФРОВОї ЕКОНОМІКИ
}

\section{THE VALUE OF BUSINESS ANALYTICS FOR THE ENTERPRISE IN TERMS OF DIGITAL ECONOMY}

Розглянуто питання, присвячені актуальності використання бізнес-аналітики в діяльності підприємства в умовах иифрової економіки. Розкрито особливості інтернет-трендів розвитку иифрової галузі. Досліджено аналітику DACQ, описову аналітику DESC, прогнозну аналітику PRED, нормативну аналітику PRES ma бізнес-аналіз. Розкрито сутність бізнес-аналітики та складові частини ї иінності для підприємства в умовах цъифрової економіки. Основну иъінність бізнес-аналітики представлено синергетичними зв'язками та синергетичними результатами. Обгрунтовано сфери діяльності бізнес-аналітики, шо охоплюють роботу з інформаиією, оптимізацію бізнес-процесів, роботу зі стейкхолдерами та співпрацю з IT-департаментом підприємства. Визначено иляхи цุифрової трансформації організачійних механізмів управління підприємством.

Ключові слова: ичиррова економіка, бізнес-аналітика, підприємство, оптимізація бізнес-процесів, цінність, синергетичні зв'язки, синергетичні результати, ефективність.

Issues of use of Business Analytics in activity of the enterprise in terms of digital economy are considered. The peculiarities of the Internet trends in the development of digital industry are revealed. It is determined that the impact of digital economy on the activities of enterprises occurs through the development of supporting infrastructure, digitalization and automation of business processes, e-commerce. DACQ analytics, descriptive analytics DESC, predictive analytics PRED, prescriptive analytics PRES and business analysis are studied. The essence of Business Analytics and components of its value for the enterprise in digital economy are revealed. It is determined that Business Analytics is a basic platform in the activities of the enterprise in adapting to terms of the development of digital economy. This ensures the formation of competitive advantages and the achievement of high level of firm performance. The result of Business Analytics is a set of developed and integrated digital technologies and products. The areas of activity of Business Analytics are substantiated by work with information, optimization of business processes, and communication with stakeholders and cooperation with the IT department of the enterprise. The main value of Business Analytics is represented by synergistic relationship and synergistic outcome, which are manifested by increased efficiency of internal and external communications, the formation of a unique user experience, quick reactions to environmental changes, management of risks and opportunities, innovations, improving the efficiency of business processes and the enterprise. To effectively use the Business Analytics, it is proposed to develop an appropriate analytical (digital) strategy, which involves the integration of the business analytical system into all functional areas of the enterprise, to develop analytical competencies by focusing on human resources and technology. The role of business analyst in the activity of the enterprise is determined. The ways of digital transformation of organizational mechanisms of enterprise management are determined.

Keywords: digital economy, Business Analytics, enterprise, optimization of business process, value, synergistic relationship, synergistic outcome, efficiency. 
Постановка проблеми. Результатом Четвертої промислової революції, яка відбувається сьогодні, є цифрова економіка «Індустрія 4.0». На відміну від автоматизації і більш ранніх технологічних трансформацій, цифровізація виходить за рамки виробництва. Вона охоплює сукупність відносин, які складаються в процесі виробництва, розподілу, обміну, споживання та базуються на цифрових технологіях, продуктах, що передбачає формування нових способів і методів ведення бізнесу та вимагає дієвих інструментів державного та муніципального регулювання.

В умовах цифрової економіки лідерів ринку визначає не багаторічна історія успіху, не активи, не доступ до капіталу чи кількість ліцензій на об'єкти інтелектуальної власності, а рівень еластичності до змін та спроможність адаптувати бізнес до нових умов цифрових трансформацій. Під останніми слід розуміти докорінне перетворення ділової та організаційної діяльності, процесів, компетенцій і моделей для забезпечення змін та можливості поєднання цифрових технологій i їx стратегічного (пріоритетного) прискорення в суспільстві з урахуванням поточного стану й майбутнього розвитку [1]. Відповідно, на цьому етапі розвитку економічних відносин особливої уваги заслуговує питання визначення передумов та особливостей використання бізнес-аналітики в управлінні підприємством.

Аналіз останніх досліджень і публікацій. Вітчизняні науковці широко розглядають сутність цифрової економіки та ії вплив на систему управління підприємством [2; 3], однак питання розвитку бізнес-аналітики в умовах цифрової економіки вивчено недостатньо. Водночас зарубіжні колеги постійно збільшують напрацювання в цьому напрямі. Ними активно досліджуються сутність бізнес-аналітики [4; 5], впорядкування даних та інформації через бізнес-аналітику під час прийняття управлінських рішень [6; 7], вплив бізнес-аналітики на інноваційну діяльність підприємства [8; 9] та зв'язок бізнес-аналітики з показниками ефективності компаній [10-13].

Сьогодні розвиток теорії та практики бізнесаналітики в українських реаліях перебуває на початковому етапі, що потребує відповідних напрацювань у сфері формування та реалізації стратегій ії розвитку. Першочерговим питанням для додаткових досліджень $є$ вивчення ролі бізнес-аналітики на сучасному етапі розвитку економіки, переваг та труднощів ії розвитку.

Мета статті полягає у розкритті передумов використання бізнес-аналітики на підприємстві в умовах цифрової економіки, обгрунтуванні сутності бізнес-аналітики та складових частин іiі цінності.
Виклад основного матеріалу. Згідно зі звітами про стан цифрової сфери Global Digital 2020 та 2021 років [8; 9], спостерігаються такі тренди.

1) Станом на січень 2021 року рівень проникнення Інтернету у всьому світі становить $59,5 \%$. Протягом останніх років річні темпи приросту становлять 7-7,3\%.

2) Станом на січень 2021 року мобільним телефоном користуються 5,22 мільярди осіб, або 66,6\% світового населення. На мобільні додатки тепер доводиться 10 із кожних 11 хвилин користування мобільним пристроєм, а на перегляд вебсторінок йде тільки 9\% «мобільного часу». Користувачі використовують додатки практично у всіх сферах життя, зокрема спілкуванні з друзями і сім'єю, управлінні фінансами, занятті фітнесом.

3) Станом на січень 2021 року у світі налічується 4,20 мільярди користувачів соціальних мереж, або 53,6\% світового населення. За рік ця цифра зросла більш ніж на 13\%. Приблизно 45\% інтернет-користувачів у всьому світі звертаються до соціальних мереж, коли шукають інформацію про товари або послуги з наміром їх придбати.

4) Подальший стрімкий розвиток електронної комерції через пандемію COVID-19. Майже 77\% користувачів Інтернету з усього світу віком від 16 до 64 років роблять покупки онлайн кожен місяць. Це означає, що за останній рік люди закріпили нові звички, пов'язані 3 онлайн-шопінгом.

5) Користувачі все менше довіряють тому, що вони бачать і чують в Інтернеті. 56\% опитаних віком від 18 років заявили, що «стурбовані» достовірністю фактів в Інтернеті. За рік відбулося зростання показника на 2\%. Кількість людей, які використовують блокувач реклами, на початку 2020 року становила 50\%, що на $3 \%$ більше порівняно з попереднім роком.

Головними інтернет-трендами в подальшому розвитку цифрової галузі визначено такі.

1) Припинення використання сторонніх файлів cookie. Рекламодавці сильно залежали від cookie, і в найближчому майбутньому їм доведеться змінити підхід до роботи. Доведеться перебудовувати діяльність під нові рекламні реалії.

2) Гнучкі умови праці. «Робота дистанційно» залишиться невід'ємною частиною трудового життя багатьох людей, тому варто очікувати появи нових продуктів і послуг, які покликані допомогти організувати віддалену роботу, в тому числі щодо спілкування й підвищення згуртованості команди.

3) Цифрова революція. Продукти та послуги, які передбачають вихід в Інтернет, будуть і далі впливати на наявні категорії 
товарів і послуг, а також провокувати появу нових. Суттєвих змін очікують галузі охорони здоров'я, фінансів та освіти.

Карантинні обмеження пандемії COVID-19є додатковим каталізатором розвитку цифрових технологій та продуктів, що сприяє поширенню електронної комерції; роботі підприємств та організацій в онлайн-режимі (особлива сфера послуг); автоматизації низки бізнес-процесів (маркетингу, сервісу, логістики, документообігу, управління персоналом, облікових систем тощо); роботизації окремих операцій; віддаленому обслуговуванню інформаційних систем, мереж та частково бізнес-процесів розробниками програмних продуктів і персоналом з підтримки; дистанційного виконання завдань та функцій; поширенню дистанційного повноцінного навчання, включаючи проведення контролю знань учасників в онлайн-режимі, зокрема дистанційного підвищення кваліфікації. Однак, не беручи до уваги пандемію, ще у 2018 році прогнозувалось, що цифрову сферу може формувати понад 300-400 тис. нових робочих місць по усій країні [2].

Описана ситуація $\epsilon$ поштовхом до зміни підходів у методах ведення бізнесу й системі управління та вагомою причиною активізації інтегрування інструментів цифрових технологій та цифрових продуктів у бізнес-процеси. Сьогодні для підприємств актуально використовувати не одну, а цілий комплекс інтегрованих цифрових технологій, продуктів (BioTech, NanoTech, RetailTech,FinTech,LegalTech,InsurTech, GovTech, BlockChain, Digital marketing, CRM\&BPM на платформі bpm'online, Grid-технологіï, Digitalстрахування, ePrescription, TeleHealth) [2]. Таким чином, вплив цифрової економіки на діяльність підприємств відбувається шляхом розвитку підтримуючої інфраструктури (програмне забезпечення, телекомунікації, мережі, бази даних); цифровізації та автоматизації бізнес-процесів; електронної комерції.

Відповідно, ключовими напрямами трансформації організаційних механізмів розвитку підприємств $\epsilon$ технологічна автоматизація бізнес-процесів на підприємствах; автоматизація бізнес-комунікацій; забезпечення офісів підприємств сучасними IT-інструментами та механізмами (новими каналами зв'язку, мережами, центрами обробки даних і серверами); впровадження системи бюджетування та єдиного електронного документообігу; глибинний розвиток IT-інфраструктури; перехід на хмарний серверний простір [2].

Перші два пункти та третій пункт щодо оброблення даних охоплюють сферу діяльності бізнес-аналітики. Вона передбачає збирання та оброблення даних (DACQ), викорис- тання баз даних, статистичний і кількісний аналізи (описова аналітика DESC), розроблення пояснювальних і прогнозних моделей (прогнозна аналітика PRED, нормативна аналітика PRES), бізнес-аналіз. Така діяльність формує доказову базу для прийняття та реалізації оперативних і стратегічних рішень розвитку підприємства, впровадження цифрових технологій та продуктів у діяльність в умовах цифрової економіки. Аналітика DACQ витягує дані з нових і застарілих систем, внутрішніх та зовнішніх джерел, а також консолідує, узагальнює та завантажує їх у різні типи інструментів бізнес-аналітики [12].

Описова аналітика DESC включає збирання, систематизацію, подання даних у табличній формі, виділення їх основних характеристик. Вона надає актуальну інформацію про минулі чи поточні події, відповідаючи на питання «Що сталося?» та «Що відбувається?», здійснює моніторинг певних показників, порівнюючи їх із пороговими значеннями. Аналітика DESC впроваджується 3 такими програмами інформаційних систем як інформаційні панелі, картки показників, візуалізація даних та аналітична обробка в режимі онлайн (OLAP) для моніторингу господарських операцій [12].

Прогнозна аналітика PRED прогнозує динаміку показників у майбутньому на основі даних за минулі періоди. Спочатку визначаються зв'язки між змінними, потім на основі їх аналізу оцінюється ймовірність тієї чи іншої події, надається прогноз майбутніх подій. Вона передбачає отримання знань із додатків DESC для прогнозування поведінкових рухів можливих майбутніх подій за допомогою алгоритмічного аналізу. Додатки PRED - це ті, які переносять великі дані у виразну, оперативну ділову інформацію [4]. Вони впроваджуються з такими додатками інформаційних систем, як аналіз ринку, інвестиційний аналіз, пошук даних та системи підтримки прийняття рішень [12].

Нормативна аналітика PRES використовує оптимізацію, моделювання, штучний інтелект, обгрунтування на основі конкретних випадків, варіанти дій і показує ймовірний результат кожного рішення. Вона $\epsilon$ математичним прийомом, який визначає оптимальний набір альтернативних методів або рішень для складної ситуації [4], розробляє та створює нові інновації, розподіляючи для них ресурси з належним обгрунтуванням [5]. Аналіз даних, розроблення продуктів та системи електронної комерції вбудовані в PRES як найпоширеніші інструменти та програми інформаційних систем [12].

Метою бізнес-аналізу є визначення потреб бізнесу та шляхів вирішення виявлених про- 
блем. Це передбачає використання таких інструментів і методів, як SWOT, PEST, Парето-аналіз, бенчмаркінг, методи портфельного аналізу.

Таким чином, бізнес-аналітика виступає базовою платформою у діяльності підприємства в адаптації умовам розвитку цифрової економіки, забезпечуючи формування конкурентних переваг та досягнення високих показників ефективності. Слід зазначити, що підприємства 3 найкращими результатами набагато частіше i ширше використовують рішення бізнес-аналітики. Менеджери підтримують адаптацію інструментів бізнес-аналітики на підприємствах із групи високопродуктивних у $41 \%$ випадків, середньопродуктивних - у $26 \%$, низькопродуктивних - лише у $21 \%$. Важливим аспектом дій менеджерів у цій сфері $є$ також побудова співпраці навколо аналітики. Керівники підприємств із групи високопродуктивних у 15,5 разів частіше, ніж представники групи низькопродуктивних визнають, що вони співпрацюють зі своїми колегами на основі інформації, отриманої 3 аналітичних інструментів. У процесі прийняття рішень використовується велика кількість джерел даних. Протягом кількох років кількість джерел даних, які підприємства матимуть аналізувати, зросте більш ніж на 80\%. Ця ситуація вимагає автоматизації аналітики. Менеджери наголошують на тому, що відсутність автоматизації призводить до проблем та викликів [11].

На рис. 1 графічно представлено сутність бізнес-аналітики та складові частини ㄲï цінності для підприємства в умовах цифрової економіки. Результатом бізнес-аналітики $є$ комплекс розроблених та інтегрованих цифрових технологій і продуктів. Цифрові продукти як процеси й послуги включають електронний обмін повідомленнями, бізнеспроцеси (замовлення, бухгалтерський облік, ведення обліку товарів, укладення контрактів тощо), дистанційне навчання, послуги в режимі реального часу (online).

Діяльність бізнес-аналітики охоплює роботу з інформацією, оптимізацію бізнес-процесів, роботу зі стейкхолдерами та співпрацю 3 ІТ-департаментом підприємства. Масове оцифрування повсякденного життя, поширена комп'ютеризація бізнес-процесів, зростання обчислювальних можливостей процесорів та різке зниження вартості зберігання даних приводять до стрімкого зростання обсягу даних (великих даних). Відповідно, все більше підприємств намагаються налагодити ефективну роботу 3 ними для створення конкурентних переваг, таких як швидкість, точність, повнота, своєчасність, економність отримання релевантної інформації. Аналітика дає можливість відокремити важливі факти від інформаційного шуму та створити нову якість продуктів i рішень на основі великих даних. Завдання бізнес-аналітики у роботі з великими даними забезпечує ланцюжок створення цінної інформації, перетворення величезної кількості необроблених даних у змістовну, своєчасну та релевантну інформацію.

Наступною перевагою використання бізнес-аналітики в рамках роботи 3 інформацією $€$ якісний рівень сканування навколишнього середовища. Це дає змогу вчасно отримувати інформацію про зміну середовища підприємства, про потреби в інноваціях, що є наслідком змін бажань клієнтів, моделей покупки, нових розробок конкурентів, змінених бізнес-моделей роботи контрагентів. Застосування бізнес-аналітики включає веб-аналітику, маркетингову аналітику, аналітику клієнтів, аналітику постачальників, аналітику конкурентів, аналітику можливостей навчання персоналу, аналітику ризиків тощо. Програми бізнес-аналітики $€$ драйвером для більшої кількості різних способів сканування навколишнього середовища [9].

Виклики цього етапу розвитку цифрової економіки обумовлює здатність управлінського персоналу визначати інформаційні потреби та шляхи їх задоволення. У нього переконання має не тільки формуватися щодо важливого значення інформації в управлінні, але й виражатися в конкретних діях, спрямованих на охоплення інформаційною системою зовнішніх та внутрішніх умов функціонування підприємств. Такі можливості підкріплюються технологічною інфраструктурою для зберігання та оброблення даних, а також людськими навичками та знаннями для фактичного перетворення даних у цінну інформацію [6].

3 точки зору роботи зі стейкхолдерами роль бізнес-аналітики в системі управління підприємством полягає в тому, щоб обгрунтовувати управлінські рішення та напрями розвитку, забезпечуючи збалансоване дотримання вимог найважливіших стейкхолдерів. Під вимогами розуміємо цільове рішення для досягнення певних бізнес-цілей або завдань, докладний опис потреб бізнесу. Фактично це документально оформлені умови або характеристики, необхідні стейкхолдерам для вирішення їх проблем або досягнення їхніх цілей, які повинні бути задоволені системою в межах стратегії розвитку підприємства з урахуванням його інтересів, тобто ці вимоги повинні задовольнятися без нанесення шкоди самій системі і сприяти підвищенню її ефективності. Аналіз вимог вимагає змістовного аналізу самого бізнесу, виявлення всього кола його стейкхолдерів та їх класифікації за ступенем необхідності враху- 


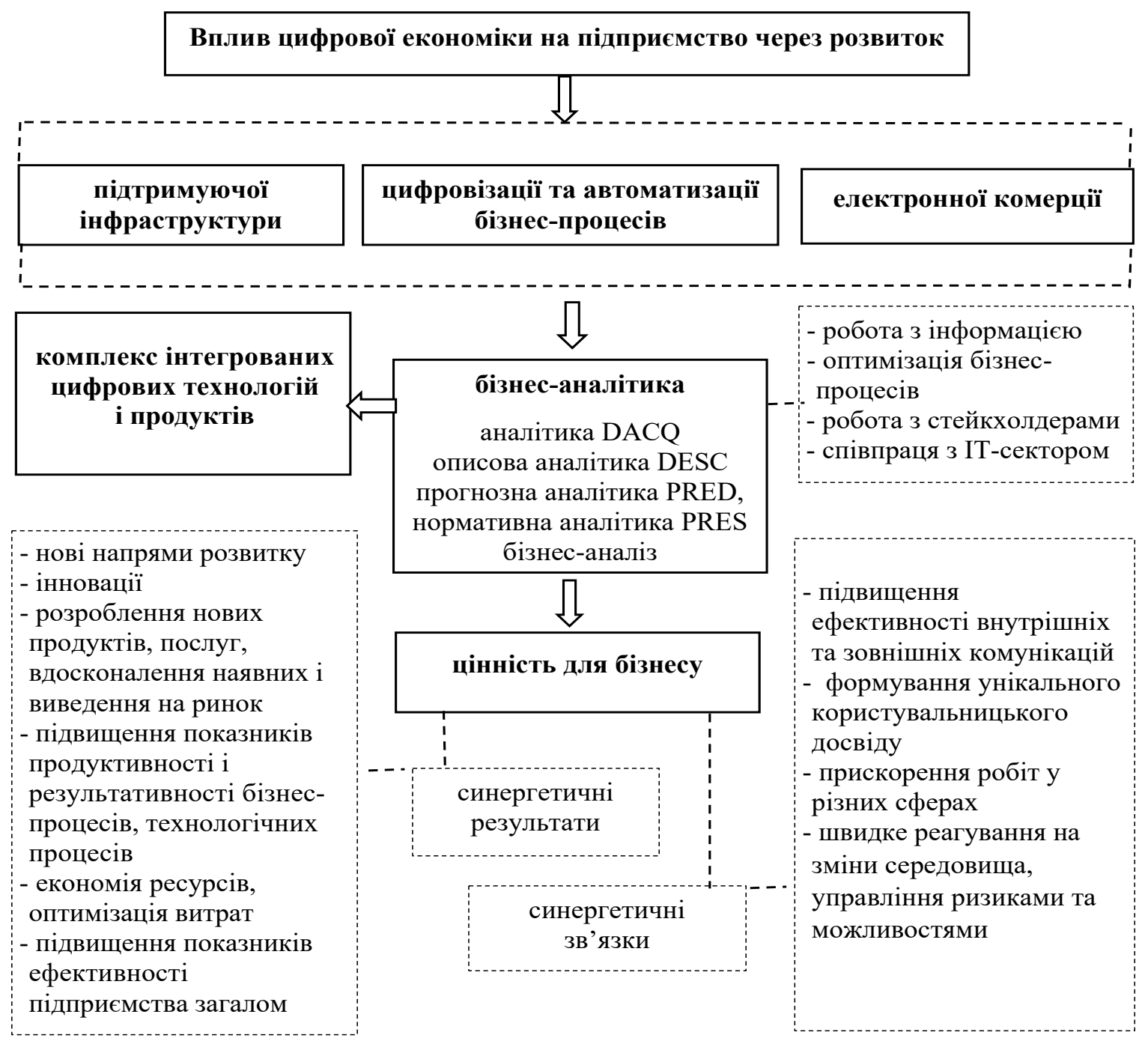

Рис. 1. Сутність бізнес-аналітики та її складові цінності для підприсмства в умовах цифрової економіки

вання їх вимог. Особливо важливо оцінити ступінь впливу на організацію, якою вони володіють. Динамічність соціально-економічних процесів і мінливість ринкової кон'юнктури зумовлюють зміни у вимогах стейкхолдерів, тому одним 3 найважливіших завдань бізнесаналітики слід вважати моніторинг змін вимог стейкхолдерів у процесі поточної діяльності компанії, в процесі реалізації проєктів, на етапі функціонування об'єкта після впровадження нововведень. Виявлені зміни повинні служити підставою для коригування проєктів або для розроблення нових інновацій. Ефективне використання бізнес-аналітики покращує орієнтацію на клієнта, дає змогу досягати чіткого розуміння й вигідної співпраці з іншим стейкхолдерами, допомагає досягати показників ефективності роботи цілого підприємства.

Бізнес-процеси - це те, як організація керує своїми ключовими операціями, які ведуть до зростання та успіху бізнесу [10]. Цілісні програми бізнес-аналітики сприяють критичній взаємозалежності між вхідними даними, процесами та результатами, що, відповідно, дає змогу створювати причинно-наслідковий зв'язок між бізнес-процесами та показниками ефективності підприємства. Бізнес-аналітика передбачає на основі вивчення бізнес-процесів підприємства здійснювати їх моделювання, перебудову, оптимізацію, впровадження цифрових технологій та продуктів. Цілями аналітичного моделювання бізнес-процесів є різні аспекти діяльності компанії, включаючи оптимізацію технологічних процесів, організаційної структури, функцій департаментів i виконавців, удосконалення документообігу та систем інформаційного забезпечення управління. Впровадження цифрових продуктів та технологій $\epsilon$ актуальним для бізнес-процесів усіх функціональних сфер діяльності, зокрема виробничої, логістичної, 
збутової. Саме вони дають змогу формувати стійкі конкурентні переваги, джерела економії ресурсів, джерела підвищення ефективності роботи підприємства, інновації.

Співпраця з IT-департаментом передбачає, що бізнес-аналітика виступає сполучною ланкою між керівництвом (вищим керівництвом, керівниками відділів) і технологічним відділом (розробниками програмного забезпечення) або ІТ-компанією, з якою співпрацює на умовах аутсорсингу. Її функції полягають в оптимізації бізнес-процесів або в розробленні нових чи вдосконаленні наявних бекенд- i фронтенд-систем. Фактично бізнес-аналітика виступає платформою перекладу з бізнес-мови технічною мовою вимог до конкретного проєкту оптимізації бізнес-процесу, розроблення для цього відповідних цифрових продуктів.

Основну цінність бізнес-аналітики представлено синергетичними зв'язками та синергетичними результатами. Синергетичні зв'язки уособлюють системне поєднання матеріальних, нематеріальних, інформаційних, комунікаційних та конкурентних зв'язків. Це змушує систему налаштовуватися на більш продуктивний, ефективний характер роботи та вчасно реагувати на зміни як у зовнішньому, так і у внутрішньому середовищі. Синергетичний зв'язок між системами бізнес-аналітики та системами управління функціональними сферами проявляється через здатність систем працювати разом, охоплювати свої межі та доповнювати одна одну. Він формує такі складові цінності бізнес-аналітики, як підвищення ефективності внутрішніх та зовнішніх комунікацій, формування унікального користувальницького досвіду, прискорення робіт у різних сферах, швидке реагування на зміни середовища, управління ризиками та можливостями.

Синергетичні результати - це нові системи управління функціональними сферами, що підтримують бізнес-аналітику, які виникають iз синергетичних зв'язків між відповідними системами. Вони включають компоненти та властивості, що виникають у результаті їх взаємодії і сприяють транзакційній, комунікаційній, інформаційній, операційній та стратегічній цінностям. Наприклад, для системи управління відносинами 3 клієнтами цим $є$ можливість перехресного продажу та підвищення продажів на основі передових обчислювальних методів [13]. Синергетичні результати формують такі складові цінності бізнес-аналітики, як нові напрями розвитку, інновації, розроблення нових продуктів, послуг, вдосконалення наявних і виведення на ринок, підвищення показників продуктивності і результативності бізнес-процесів, технологічних процесів, економія ресурсів, оптимізація витрат, підвищення показників ефективності підприємства загалом.

В динамічних та складних бізнес-середовищах використання бізнес-аналітики, iї цифрових технологій та продуктів впливає на окремого користувача у його роботі, і ці індивідуальні впливи у сукупності приводять до організаційних впливів на ефективність окремих бізнес-процесів та підприємства загалом. Таким чином, програми бізнес-аналітики допомагають краще зрозуміти динаміку бізнесу, коригувати прогнози ринку, перевіряти обгрунтованість стратегічних векторів розвитку, зменшувати ризики реалізації інвестиційних проєктів, підвищувати ефективність бізнес-процесів, оптимізувати ділові операції, прогнозувати результати, впроваджувати нові продукти та послуги. Це сприяє формуванню стійкого рівня конкурентоспроможності та високої стійкості до зовнішніх флуктуацій, наслідком чого для підприємства є збільшення фінансової вартості компанії, зростання виплат по дивідендах, підвищення ліквідності, розвиток соціальної відповідальності, а для працівників - підвищення заробітної плати, зростання рівня професійних знань та навичок, покращення соціально-економічних умов праці.

Перераховані цінності використання бізнесаналітики у діяльності підприємства свідчать про потребу у відповідних інвестиціях ії розвитку. Д. Кірон визначає, що компанії, які мають успіх у застосуванні бізнес-аналітики, не просто розглядають аналітику як важливий шлях до цінності, але й розвиваються і змінюються як організації в результаті свого досвіду роботи 3 аналітикою [8]. Для ефективності використання системи бізнес-аналітики потрібно розробити відповідну аналітичну (цифрову) стратегію, що передбачає інтеграцію системи бізнес-аналітики в усі функціональні сфери діяльності підприємства, розвиток аналітичних компетенцій із зосередженням на людських ресурсах і технологіях. Підприємства повинні заохочувати співробітників бути відкритими до нових ідей та підходів на основі нової інформації, використовувати аналітичну інформацію на основі даних для створення нових продуктів (послуг), визначати потребу в даних для прийняття рішень, використовувати доказову базу для підтримки прийняття рішень, розуміти цінність даних та інформації в організації. Встановлення лише інструментів бізнес-аналітики на робочому місці не приведе автоматично до нових знань та інновацій. Це не може бути залишено IT-відділу або спеціалізованій групі 3 аналізу даних, адже вона повинна включати усіх, хто зацікавлений у 
інноваціях. Робота бізнес-аналітиків - це не лише технічна сторона аналізу, але й допомога решті організації зрозуміти зміст і значення їх висновків, що має вирішальне значення під час прийняття управлінських рішень [9].

Таким чином, бізнес-аналітик - це фахівець, який покликаний допомагати підприємству стійко розвиватися, формуючи нові або вдосконалюючи наявні напрями ділової активності, оптимізуючи основні й допоміжні бізнес-процеси відповідно до іiі стратегічних цілей і запитів стейкхолдерів. Роль бізнес-аналітика значною мірою залежить від специфіки роботи підприємства та його потреб, а також ступеня усвідомлення необхідності створення посади бізнес-аналітика та іiі функцій. У класифікаторі професій ДК 003:2010 Національного класифікатора України, чинного від 1 листопада 2010 року, немає професії бізнес-аналітика. Такої професії не зазначено і в Міжнародній стандартній класифікації професій (2012 рік).

Однак сьогодні пропозиція вакансій на ринку праці охоплена величезною кількістю посад бізнес-аналітика в різноманітних сферах, зокрема IT, торговельна, фармацевтична, фінансова, телекомунікаційна. Обов'язки бізнес-аналітика в команді можуть варіюватися, однак у всіх вакансіях зазначені такі основні функції, як стратегічний аналіз (робота над стратегією розвитку та проєктами в різних функціональних сферах); управління вимогами (їх визначення, деталізація, подальший моніторинг); проєктування рішень (підготовка документації і створення прототипів, обгрунтування й донесення до команди сутності рішення та шляху імплементації); управління продуктом (комунікація
3 дизайнерами, інженерами, маркетологами та стейкхолдерами). Навички бізнес-аналітика доречно розділити на такі три групи, як фундаментальні навики, технічні навики, навички бізнес-аналізу. Також потрібно зазначити, що робота над цифровими продуктами та впровадження цифрових технологій передбачає на практиці використання проєктного підходу. Бізнес-аналітик працює 3 різними зацікавленими сторонами організації, щоб уточнити i доопрацювати вимоги, допомагає команді в розробленні проєкту, перевірці розроблених компонентів. Це людина, яка володіє достатніми знаннями в предметній галузі.

Окрім спеціально створених посад бізнесаналітиків, функції бізнес-аналітики частково можуть виконувати інші фахівці. Це менеджери середнього рівня управління (лінійні та функціональні), головні інженери виробництва, інженери у сфері оброблення даних, фахівці з економічного аналізу і фінансові аналітики тощо. В IT-компаніях, які розробляють цифрові технології і продукти для клієнтів у різних сферах діяльності, функції бізнес-аналітики також на себе беруть найдосвідченіший розробник-девелопер, QA-інженер, Scrum-майстер, якщо команда працює за моделлю Agile.

Ефективне використання бізнес-аналітики потребує цифрової трансформації організаційних механізмів управління підприємством, що передбачає таке.

1) Розвиток IT-інфраструктури $з$ єдиною системою IT-підтримки користувачів, тобто організацію програмного забезпечення підприємства, обчислювальних програм, бази даних та інших ресурсів, які, об’єднуючись

\section{Професії та професійні назви робіт у рамках бізнес-аналітики}

Таблиця 1

\begin{tabular}{|c|c|}
\hline $\begin{array}{c}\text { Класифікатор професій ДК 003:2010 } \\
\text { Національного класифікатора України }\end{array}$ & $\begin{array}{l}\text { International Standard Classification of } \\
\text { Occupations }\end{array}$ \\
\hline $\begin{array}{l}2131.2 \text { - аналітик із комп’ютерних комунікацій, } \\
\text { аналітик комп’ютерних систем, аналітик комп'ютерного } \\
\text { банку даних, аналітик операційного та прикладного } \\
\text { забезпечення, аналітик програмного забезпечення } \\
\text { та мультимедіа }\end{array}$ & $\begin{array}{l}2511 \text { Systems Analysts } \\
\text { 251 Software and Applications Developers and } \\
\text { Analysts } \\
\text { 25 Information and Communications Technology } \\
\text { Professionals }\end{array}$ \\
\hline $\begin{array}{l}2419.2 \text { - консультант, консультант з ефективності } \\
\text { підприємництва, консультант із раціоналізації } \\
\text { виробництва, консультант з ефективності підприємництва, } \\
\text { консультант з раціоналізації виробництва }\end{array}$ & 1213 Policy and Planning Managers \\
\hline 2414.2 - аналітик із питань фінансово-економічної безпеки & $\begin{array}{l}13 \text { Production and Specialized Services Managers } \\
\text { (in different branches of economy) }\end{array}$ \\
\hline $\begin{array}{l}2441.2 \text { - аналітик (банківська справа), аналітик } 3 \\
\text { інвестицій, аналітик з кредитування }\end{array}$ & \\
\hline 2441.2/23068 - консультант з економічних питань & \\
\hline $\begin{array}{l}14 \text { - менеджери підприємств, установ, організацій та їх } \\
\text { підрозділів }\end{array}$ & \\
\hline
\end{tabular}

Джерело: сформовано авторами на основі [16; 17$]$ 
через Інтернет, працюють у зв'язці. Це дає змогу ефективно виконувати бізнес-завдання і створювати бізнес-середовище для скоординованої роботи всього підприємства і кожного підрозділу, які можуть бути фізично віддалені один від одного.

2) Розвиток швидкої, уніфікованої, безпечної системи обміну інформацією для прийняття стратегічних та операційних рішень, швидкої реакції на зміни, а також операційної ефективності.

3) Розвиток баз даних із диференційованим доступом для різних рівнів управлінських ланок для прийняття управлінських рішень.

4) Розвиток цифрових платформ, за допомого яких реалізується інформаційний обмін між різними групами користувачів без задіяння посередників. Зокрема, в рамках клієнтоорієнтованості це дає змогу об'єднати всі необхідні інструменти для персоналізації, детального обчислення, комерції, орієнтованої на прибуток, передової аналітики та прицільного таргетування задля повноцінного розуміння клієнтів та їхніх індивідуальних потреб, а також побудови довгострокових лояльних відносин.

5) Впровадження цифрових технологій управління.

6) Трансформації технології складових частин операційного процесу 3 фізичного управління процесами людиною у цифрові.

7) Впровадження штучного інтелекту, який $є$ розробленням технологічних рішень, що працюють за принципом людського інтелекту або близько до нього. Системи штучного інтелекту можуть оперувати даними та самонавчатися. Основні сфери застосування цих систем пов'язані з підтримкою прийняття управлінських рішень у таких напрямах біз- несу, як кредитування й оцінювання ризиків, маркетинговий аналіз, прогнозування фінансових ринків, моделювання функціональних складових частин менеджменту (фінанси, виробництво, людські ресурси), розв'язання прикладних соціологічних задач, управління бюджетними ресурсами й економічне моделювання. Штучний інтелект здатний допомогти оптимізувати процеси в медицині, автомобільній промисловості, фінансах, торгівлі й багатьох інших сферах.

Висновки. Цифрові технології допомагають знайти джерела підвищення ефективності бізнес-процесів та можливості формування стійких конкурентних переваг підприємств, що вимагає зміни наявних моделей управління. Це потребує перебудови організаційної структури, системи комунікації, технологічних процесів на основі пріоритетів та орієнтирів цифровізації. Цифрова стратегія та ефективність системи бізнес-аналітики відображає рівень цифрової зрілості підприємства. Бізнес-аналітика спрямована на розроблення рішень комплексним інтегрованим підходом, що базується на роботі з інформацією, оптимізацією бізнес-процесів, роботі зі стейкхолдерами та співпраці з IT-департаментом підприємства. Отримані синергетичні зв'язки та синергетичні результати формують елементи цінності для бізнесу, такі як підвищення ефективності внутрішніх та зовнішніх комунікацій, формування унікального користувальницького досвіду, прискорення робіт у різних сферах, швидке реагування на зміни середовища, управління ризиками та можливостями, розроблення нових напрямів розвитку, інновацій, оптимізація витрат, підвищення показників ефективності бізнес-процесів та підприємства загалом.

\section{Список використаних джерел:}

1. What is digital business transformation? The essential guide to DX. Digital transformation: online guide to digital business transformation. URL: https://www.i-scoop.eu/digital-transformation (дата звернення: 17.08.2021).

2. Гудзь О.С. Цифрова економіка: зміна цінностей та орієнтирів управління підприємствами. Економіка. Менеджмент. Бізнес. 2018. № 2(24). С. 4-10.

3. Фостолович В.А. Формування сучасних інтегрованих систем управління підприємством із застосуванням цифрових технологій. Sciences of Europe. 2020. № 50. С. 70-80.

4. Bayrak T. A review of business analytics: A business enabler or another passing fad. Procedia-Social and Behavioral Sciences. 2015. July. Vol. 195. P. 230-239.

5. Hindle G., Vidgen R. Developing a business analytics methodology: A case study in the foodbank sector. European Journal of Operational Research. 2018. Vol. 268. Issue 3. P. 836-851.

6. Gupta M., George, J. Toward the development of a big data analytics capability. Information \& Management. 2016. Vol. 53. Issue 8. P. 1049-1064.

7. Mikalef P., Pappas I., Krogstie J., Pavlou P. Big data and business analytics: A research agenda for realizing business value. Information \& Management. 2020. Vol. 57. Issue 1. URL: https://www.researchgate.net/ publication/337543997_Big_data_and_business_analytics_A_research_agenda_for_realizing_business_value (дата звернення: $17.08 .202 \overline{1}$ ).

8. Kiron, D., Prentice P., Ferguson R. Innovating with analytics. MIT Sloan Management Review. 2012. Vol. 54. Issue 1. P. 47-52. 
9. Duan Y., Cao G., Edwards J.S. Understanding the impact of business analytics on innovation. European Journal of Operational Research. 2020. Vol. 281. Issue 3. P. 673-686.

10. Mithas S., Ramasubbu N., Sambamurthy V. How information management capability influences firm performance. MIS Quarterly. 2011. Vol. 35. Issue 1. P. 237-256.

11. Kościelniak H., Łęgowik-Świącik S., Jančíková E. Business analytics of enterprises in terms of strategy. Polish journal of management studies. 2017. Vol. 16. No. 1. P. 67-77.

12. Aydiner A., Tatoglu E., Bayraktar E., Zaim S., Delen D. Business analytics and firm performance: The mediating role of business process performance. Journal of Business Research. 2019. Vol. 96. P. 228-237.

13. Someh I., Shanks G., Davern M. Reconceptualizing synergy to explain the value of business analytics systems. Journal of Information Technology. 2019. February. URL: https://journals.sagepub.com/doi/ abs/10.1177/0268396218816210 (дата звернення: 17.08.2021).

14. Digital 2020: Global digital overview. URL: https://datareportal.com/reports/digital-2020-global-digital-overview (дата звернення: 18.08.2021).

15. Digital 2021: Global digital overview. URL: https://datareportal.com/reports/digital-2021-global-overview-report (дата звернення: 18.08.2021).

16. Класифікатор професій ДК 003:2010 Національного класифікатора України. URL: https://zakon.rada.gov.ua/rada/show/va327609-10\#Text (дата звернення: 20.08.2021).

17. International Standard Classification of Occupations. URL: https://www.ilo.org/wcmsp5/groups/public/--dgreports/---dcomm/---publ/documents/publication/wcms_172572.pdf (дата звернення: 20.08.2021).

\section{References:}

1. What is digital business transformation? The essential guide to DX. Digital transformation: online guide to digital business transformation. Available at: https://www.i-scoop.eu/digital-transformation (accessed 17 August 2021).

2. Ghudzj O.Je. Tsyfrova ekonomika: zmina tsinnostei ta oriientyriv upravlinnia pidpryiemstvamy (2018) [Digital economy: changing values and guidelines of enterprise management]. Economy. Management. Business, vol. 24, no. 2, pp. 4-10.

3. Fostolovych V.A. (2020) Formuvannia suchasnykh intehrovanykh system upravlinnia pidpryiemstvom iz zastosuvanniam tsyfrovykh tekhnolohii [Formation of modern integrated enterprise management systems with the use of digital technologies]. Sciences of Europe, no. 50, pp. 70-80.

4. Bayrak T. (2015) A review of business analytics: A business enabler or another passing fad. ProcediaSocial and Behavioral Sciences, vol. 195, pp. 230-239.

5. Hindle G., Vidgen R. (2018) Developing a business analytics methodology: A case study in the foodbank sector. European Journal of Operational Research, vol. 268, issue 3, pp. 836-851.

6. Gupta M., George J. (2016) Toward the development of a big data analytics capability. Information \& Management, vol. 53, issue 8, pp. 1049-1064.

7. Mikalef P., Pappas I., Krogstie J., Pavlou P. (2020) Big data and business analytics: A research agenda for realizing business value. Information \& Management, vol. 57, issue 1. Available at: https://www.researchgate.net/ publication/337543997_Big_data_and_business_analytics_A_research_agenda_for_realizing_business_value (accessed 17 August 2021).

8. Kiron D., Prentice P., Ferguson R. (2012) Innovating with analytics. MIT Sloan Management Review, vol. 54, issue 1, pp. 47-52.

9. Duan Y., Cao G., Edwards J.S. (2020) Understanding the impact of business analytics on innovation. European Journal of Operational Research, vol. 281, issue 3, pp. 673-686.

10. Mithas S., Ramasubbu N., Sambamurthy V. (2011) How information management capability influences firm performance. MIS Quarterly, vol. 35, issue 1, pp. 237-256.

11. Kościelniak H., Łęgowik-Swiącik S., Jančíková E. (2017) Business analytics of enterprises in terms of strategy. Polish journal of management studies, vol. 16, no. 1, pp. 67-77.

12. Aydiner A., Tatoglu E., Bayraktar E., Zaim S., Delen D. (2019) Business analytics and firm performance: The mediating role of business process performance. Journal of Business Research, vol. 96, pp. 228-237.

13. Someh I., Shanks G., Davern M. Reconceptualizing synergy to explain the value of business analytics systems. Journal of Information Technology. February. 2019. Available at: https://journals.sagepub.com/doi/ abs/10.1177/0268396218816210 (accessed 17 August 2021).

14. Digital 2020: Global digital overview. Available at https://datareportal.com/reports/digital-2020-globaldigital-overview (accessed 18 August 2021).

15. Digital 2021: Global digital overview. Available at: https://datareportal.com/reports/digital-2021-globaloverview-report (accessed 18 August 2021).

16. Classifier of professions DK 003: 2010 of the National Classifier of Ukraine. Available at: https://zakon.rada.gov.ua/rada/show/va327609-10\#Text (accessed 20 August 2021).

17. International Standard Classification of Occupations. Available at: https://www.ilo.org/wcmsp5/groups/ public/---dgreports/---dcomm/---publ/documents/publication/wcms_172572.pdf (accessed 20 August 2021). 